\title{
APACHE II, SAPS II, and SOFA Scoring Systems Used for Predicting Outcome in Acute Organophosphate Intoxicated Patients Admitted to the Intensive Care Unit-Poison Control Center Ain Shams University Hospitals (A Prospective Study)
}

\author{
Nesrine M. Sarhan ${ }^{1}$
}

${ }^{1}$ Department of Forensic Medicine and Clinical Toxicology, Faculty of Medicine, Ain-Shams University, Cairo, Egypt.

\begin{abstract}
Acute organophosphate (OP) poisoning accounts for a large number of intoxication cases treated in the Intensive Care Unit (ICU). The aim of this study is to evaluate the performance of APACHE II, SAPS II, and SOFA scoring systems for predicting mortality of OP poisoned patients admitted to the ICU. Subjects and methods: Seventy three OP intoxicated patients admitted to the ICU of the PCC-ASUH during the period from June 2013 to June 2015 were prospectively evaluated through a cross sectional hospital based study. Results: An APACHE II score of 10.5 or more was predictive of mortality, with $53.57 \%$ sensitivity and $97.78 \%$ specificity. A SAPS II score of 25 or more was predictive of mortality, with 75.00 $\%$ sensitivity and $84.44 \%$ specificity. A SOFA score of 2.5 or more was predictive of mortality, with 75.00 $\%$ sensitivity and $91.11 \%$ specificity. Conclusion: The three scoring systems, APACHE II, SAPS II, and SOFA, were more precise in differentiating the survivors from the non survivors than plasma butyrylcholinesterase.
\end{abstract}

\section{Introduction}

A cute organophosphate (OP) poisoning, due to intentional self harm exerts a major burden on the health care system and is responsible for great morbidity and mortality in developing countries (Kim et al., 2013). OP poisoning accounts for a large number of intoxication cases treated in the Intensive Care Unit (ICU) (Cander et al., 2011).The mortality rates are between 4 and 30\% despite appropriate treatment (Jalali et al., 2003).

Identification of high risk patients soon after presentation, allows more intensive monitoring and treatment. A simple system based on clinical features is likely to be most useful in low income countries where the majority of OP poisoning occurs (WHO, 2011).

Use of scoring systems particularly developed for patient assessment at the time of ICU admission has reduced many problems and facilitated treatment planning. The Acute Physiology and Chronic Health Evaluation II (APACHE II) (Kanus et al., 1985) and the Simplified Acute Physiology Score II (SAPS II) (Le Gall et al., 1993) scoring systems, as well as Sequential Organ Failure Assessment (SOFA) (Vincent et al., 1996) are three tools widely used by most ICUs to predict mortality (Hargrove and Nguyen, 2005).

Aim of the work

The purpose of this study is to evaluate the role of APACHE II, SAPS II, and SOFA scoring systems in predicting mortality of OP poisoned patients admitted to the ICU.

Hence, a 2 year prospective study was undertaken to assess the correlation of these scores with the outcome of OP poisoning cases admitted to the ICU of the Poison Control Center, Ain Shams University Hospitals (PCC-ASUH).

\section{Subjects and Methods} Subjects

Seventy three OP intoxicated patients admitted to the ICU of the PCC-ASUH during the period from June 2013 to June 2015 were prospectively evaluated through a cross sectional hospital based study. The diagnosis of 
OP intoxication was based on history of OP intake, circumstantial evidence such as availability of a poison bottle or a label found by the relatives, OP smell in gastric contents, clinical manifestations of OP toxicity and measuring serum cholinesterase level (Ahmad et al., 2009).

Exclusion criteria: Patients with any of the following conditions were excluded: 1) combined drug exposures; 2) pre-hospital cardiac arrest; 3) < 18 yr of age; or 4) severe chronic illness. Severe chronic illness included liver cirrhosis with portal hypertension, New York Heart Association class IV congestive heart failure, chronic respiratory disease, end-stage renal disease, or an immune-compromised state (e.g., leukemia, lymphoma, or AIDS).

Patients were divided into 2 groups, according to their outcome; the first group: (Survivors) included 45 patients while the second group: (Non survivors) included 28 patients.

\section{Ethics}

Approval of the Ethical Committee of Faculty of Medicine-Ain Shams University and the Head of the PCC-ASUH were obtained. Informed written consents from the patients or their relatives were obtained. They were assured that any information they provided would be kept strictly confidential and anonymous.

\section{Methods}

Data collection: for every patient, the following data were recorded:

1. Demographic data: age, sex and occupation.

2. Organ insufficiency or immuno-compromised state: must have been evident prior to the hospital admission and conform to the following criteria, according to Kanus et al., 1985.

LIVER: Biopsy proven cirrhosis and documented portal hypertension by episodes of past upper GI bleeding attributed to portal hypertension, that are documented in previous reports.

Prior episodes of hepatic failure/encephalopathy/coma.

RESPIRATORY: Chronic restrictive, obstructive, or vascular disease resulting in severe exercise restriction.

Unable to climb stairs or perform household duties: or documented chronic hypoxia, hypercapnia, secondary polycythemia, severe pulmonary hypertension (> $40 \mathrm{mmHg}$ ), or respirator dependancy.

RENAL: Recurring chronic dialysis

IMMUNO-COMPROMISED: The patient has received therapy that suppresses resistance to infection [e.g. immuno-suppresion, chemotherapy, radiation, long-term or recent high dose steroids] or has a disease that is sufficiently advanced to suppress resistance to infection [e.g. leukemia, lymphoma, AIDS]

3. Clinical manifestations: general and systemic examination was performed on admission, including systolic and mean arterial blood pressure $(\mathrm{mmHg})$, heart rate, respiratory rate, body temperature, urinary output, and conscious level, which was evaluated by applying Glasgow Coma Score (GCS).

4. Laboratory parameters ( the following parameters were measured in the first 24 hours after ICU admission)

- Arterial blood gases (ABGs) were analyzed using Rapid lab 855 of Bayer Company for assessment of the following ( $\mathrm{pH}, \mathrm{PaCO}_{2}, \mathrm{PaO}_{2}, \mathrm{SaO}_{2}$ and $\mathrm{HCO}_{3}$ ).

- Random blood sugar (Normal range: 72$144 \mathrm{mg} / \mathrm{dl}$ ) (Lehman and Krumholz, 2009).

- Serum electrolytes: serum sodium (Normal range: $135-150 \mathrm{mEq} / \mathrm{L})$ and serum potassium (Normal range: $3.5-5.5 \mathrm{mEq} / \mathrm{L}$ ) (Faix, 2000).

- Renal functions: blood urea nitrogen (Normal range: 8- $20 \mathrm{mg} / \mathrm{dl}$ ) (Lawrence and Robert, 1993) and serum creatinine: (Normal range: up to $1.4 \mathrm{mg} / \mathrm{dl}$ ) (Bazari, 2007).

- Total serum bilirubin was analyzed with a diazotized sulfanilic acid reagent and a commercial colorimetric method on a FARA II autoanalyzer (Roche) (Novros et al., 1979).

- Complete blood count (CBC) was analyzed using Medonic M-Series Open Vial Analyzer for assessment of the following (hematocrit, white blood cells and platelets).

- Plasma cholinesterase (PChE) was determined using a kinetic colorimetric method according to Waber (1966). Kits were purchased from Diamond diagnostics, Cairo, Egypt.

5. Treatment: required treatment was done according to the protocol of management of OP toxicity including intravenous atropine and oximes (Eddleston et al., 2004), under supervision of the same physicians and received equivalent nursing services by the same ICU personnel. Use of vasopressors was recorded including the dose.

6. Follow up: All patients were followed until discharge from the hospital or death. The clinical outcomes were sorted out using two variables, namely, improved status or fatal outcome. The variable 'improved status' was defined as the state of complete recovery. 'Fatality' was defined as a clinical state of brain death as certified by the physician.

The APACHE II (Kanus et al., 1985), SAPS II (Le Gall et al., 1993) and SOFA (Vincent et al., 1996) scores were calculated as in tables 1,2 , 
and 3 respectively, using Clincalc.com (Kane, 2015). The APACHE II score was calculated from 12 routine physiological and laboratory measurements (Table 1). The score for each parameter was assigned from 0 to 4 , with 0 being normal and four being the most abnormal. The sum of these values were added to a mark adjusting for patient age and a mark adjusting for chronic health problems (severe organ insufficiency or immunocompromised patients), to arrive at the APACHE II score. The resulting point score was interpreted in relation to the illness of the patient. The measurement was made during the first 24 hours following admission to the emergency ward and resulted in an integer point score between 0 and 71 . The predicted mortality rate was calculated based on the APACHE II score. Also, SAPS II and SOFA scores was calculated using the worst physiologic values in the first ICU day.

\section{CHRONIC HEALTH POINTS}

If the patient has a history of severe organ system deficiency or is immuno - compromised, assign points as follows:

a. For non-operative or emergency postoperative patients $(5$ points)

b. for selective postoperative patients (2 points)

APACHE II Score $=$ acute physiology score + age points + chronic health points. Minimum score $=0$; maximum score $=71$.

Increasing score is associated with increasing risk of hospital death.

Choose worst value in the past $24 \mathrm{~h}$.

Interpretation of APACHE II scores (predicted mortality rate).

$0-4=4 \%$ death rate

$5-9=8 \%$ death rate

$10-14=15 \%$ death rate

$15-19=25 \%$ death rate

$20-24=40 \%$ death rate

$25-29=55 \%$ death rate

$30-34=75 \%$ death rate.

Over $34=85 \%$ death rate.

\section{Statistical Analysis}

Data were analyzed using SPSS (Statistical Package for the Social Science) version 21.0 (SPSS Inc., Chicago, IL, USA). Differences between the two groups were tested using the independent two-sample t-test.

Receiver operating characteristic (ROC) curves for predicting inpatient mortality were generated using mortality as an independent variable. The sensitivities, specificities, likelihood ratios and area under the curve (AUC), an indicator of the predictive value of a test, were calculated using GraphPad Prism V6.0. The best cut-off values were calculated as the point having the maximal Youden's index (Youden's index =sensitivity + specificity) (Bewick et al., 2004).

Standardized mortality rates were also calculated to observe the difference between expected and actual mortality rates. The $95 \%$ confidence intervals (CI) for standardized mortality ratios (SMR) were calculated using the observed mortality as a Poisson variable, and then dividing its $95 \%$ CI by the predicted mortality (Goldhill and Sumner, 1998).

$\mathrm{P}<0.05$ was considered significant. $\mathrm{P}<0.001$ was considered highly significant.

\section{Results}

A clinical prospective cross sectional study was performed on OP intoxicated patients, who were admitted to the ICU of the Poison Control Center, Ain Shams University Hospitals (PCC-ASUH), from June 2013 to June 2015.

\section{Patient demographics and exposure characteristics}

Among a total of 73 OP poisoned patients agreed the inclusion criteria, females were $40(55 \%)$ and males were $33(45 \%)$. The mean age of the included patients was $33 \pm 15$ years. All cases were suicidal, and the route of exposure was oral ingestion.

\section{Clinical characteristics}

A total of $40(55 \%)$ patients required intubation and ventilator assistance. Twenty eight (38\%) patients died. Respiratory failure, including complications of mechanical ventilation was the cause of death in 24 patients, while, cardiac arrthymias that led to premature ventricular contractions and ventricular fibrillations were the cause of death in 4 patients (table 4 ).

Plasma butyrylcholinesterase was higher in the survivors, yet this was not statistically significant. Also, the delay time was shorter in the survivors, but without statistically significant difference. On the contrary, the three scoring systems, APACHE II, SAPS II, and SOFA, were highly significant in differentiating the survivors from the non survivors (table 5).

The cut-off values, sensitivities and specificities of scoring systems are shown in Table 6. An APACHE II score of 10.5 or more was predictive of mortality, with $53.57 \%$ sensitivity and $97.78 \%$ specificity. A SAPS II score of 25 or more was predictive of mortality, with $75.00 \%$ sensitivity and $84.44 \%$ specificity. A SOFA score of 2.5 or more was predictive of mortality, with $75.00 \%$ sensitivity and $91.11 \%$ specificity.

The representative ROC curves for each scoring systems are shown in Figure 1. ROC curves were drawn at different cut-off values for APACHE II, SAPS II and SOFA scores. The corresponding areas under the ROC curves were as follows: $0.777 \pm 0.058,0.8107 \pm 0.064$, and $0.8548 \pm 0.052$ respectively.

The actual, predicted and standardized mortality rates were shown in Table 7 . The actual mortality was $38 \%$. Predicted mortality rates were 30,37 and $34 \%$ for APACHE II, SAPS II, and SOFA respectively. Predicted mortality determined by APACHE II, SAPS II, and SOFA scoring systems were not significantly different from actual mortality as confidence intervals (CIs) demonstrate in Table 3. 
Table 1: Apache II -- Acute Physiology and Chronic Health Evaluation (Kanus et al., 1985)

\begin{tabular}{|c|c|c|c|c|c|c|c|c|c|}
\hline & \multicolumn{4}{|c|}{ HIGH ABNORMAL RANGE } & & \multicolumn{4}{|c|}{ LOW ABNORMAL RANGE } \\
\hline Physiological variable & +4 & +3 & +2 & +1 & 0 & +1 & +2 & +3 & +4 \\
\hline TEMPERATURE $\left({ }^{\circ} \mathrm{C}\right)$ & $>41$ & $\begin{array}{l}39- \\
40.8 \\
\end{array}$ & & $\begin{array}{l}35.5- \\
38.9\end{array}$ & $\begin{array}{l}36- \\
38.4 \\
\end{array}$ & $\begin{array}{l}34- \\
35.8 \\
\end{array}$ & $\begin{array}{l}32- \\
33.9 \\
\end{array}$ & $\begin{array}{l}30- \\
31.9 \\
\end{array}$ & $<29.9$ \\
\hline $\begin{array}{l}\text { MEAN ARTERIAL } \\
\text { PRESSURE (mm Hg) }\end{array}$ & $>160$ & $\begin{array}{l}130- \\
159\end{array}$ & & & $\begin{array}{l}70- \\
109\end{array}$ & & $50-69$ & & $<49$ \\
\hline HEART RATE (ventricular response) & $>180$ & $\begin{array}{l}140- \\
179\end{array}$ & & & $\begin{array}{l}70- \\
109\end{array}$ & & $55-69$ & & $<39$ \\
\hline $\begin{array}{l}\text { RESPIRATORY RATE } \\
\text { (non ventilated or ventilated) }\end{array}$ & $>50$ & $\begin{array}{l}35- \\
49\end{array}$ & & & $12-24$ & & $6-9$ & & $<5$ \\
\hline $\begin{array}{l}\text { OXYGENATION } \\
\mathrm{FiO} 2>0.5: \text { use } \mathrm{A}-\mathrm{aDO} 2 \\
\mathrm{FiO} 2<0.5: \text { use } \mathrm{PaO} 2(\mathrm{~mm} \mathrm{Hg})\end{array}$ & $>500$ & $\begin{array}{l}350- \\
498\end{array}$ & $\begin{array}{l}200- \\
349\end{array}$ & & $\begin{array}{l}<200 \\
\mathrm{PO},> \\
70\end{array}$ & $\begin{array}{l}200- \\
349 \\
P O, 61 \\
-70\end{array}$ & $\begin{array}{l}200- \\
349\end{array}$ & $\begin{array}{l}200- \\
349 \\
\mathrm{PO} \\
55-60\end{array}$ & $\begin{array}{l}200- \\
349 \\
\mathrm{PO},< \\
55\end{array}$ \\
\hline ARTERIAL pH & $>7.7$ & $\begin{array}{l}7.6- \\
7.69\end{array}$ & & $\begin{array}{l}7.5- \\
7.59\end{array}$ & $\begin{array}{l}7.33- \\
7.49\end{array}$ & & $\begin{array}{l}7.15- \\
7.32\end{array}$ & $\begin{array}{l}7.15- \\
7.24\end{array}$ & $<7.15$ \\
\hline SERUM SODIUM (meg/dl) & $>180$ & $\begin{array}{l}160- \\
179 \\
\end{array}$ & $\begin{array}{l}155- \\
159\end{array}$ & $\begin{array}{l}150- \\
154 \\
\end{array}$ & $\begin{array}{l}130- \\
149 \\
\end{array}$ & & $\begin{array}{l}120- \\
129 \\
\end{array}$ & $\begin{array}{l}11- \\
119 \\
\end{array}$ & $<110$ \\
\hline SERUM POTASSIUM (meg/dl) & $>7$ & $6-6.9$ & & $\begin{array}{l}5.5- \\
5.9\end{array}$ & $\begin{array}{l}3.5- \\
5.4\end{array}$ & $3-3.4$ & $\begin{array}{l}2.5- \\
2.9\end{array}$ & & $<2.5$ \\
\hline $\begin{array}{l}\text { SERUM CREATININE }(\mathrm{mg} / 100 \mathrm{ml}) \\
\text { double point score } \\
\text { for acute renal failure }\end{array}$ & $>3.5$ & $2-3.4$ & $\begin{array}{l}1.5- \\
1.9\end{array}$ & $\begin{array}{l}0.6- \\
1.4\end{array}$ & & & $<0.6$ & & \\
\hline HEMATOCRIT $(\%)$ & $>60$ & & $\begin{array}{l}50- \\
59.9\end{array}$ & $\begin{array}{l}48- \\
49.9\end{array}$ & $\begin{array}{l}30- \\
45.9\end{array}$ & & $\begin{array}{l}20- \\
29.9\end{array}$ & & $<20$ \\
\hline $\begin{array}{l}\text { WHITE BLOOD } \\
\text { COUNT (total/mm3) (in 1000s) }\end{array}$ & $>40$ & & $\begin{array}{l}20- \\
39.9\end{array}$ & $\begin{array}{l}15- \\
19.9\end{array}$ & $\begin{array}{l}3- \\
14.9\end{array}$ & & $1-2.9$ & & $<1$ \\
\hline $\begin{array}{l}\text { GLASGOW COMA SCORE (GCS) } \\
\text { (score } 15 \text { minus actual GCS) }\end{array}$ & Score & $=15 \mathrm{mir}$ & s actue & $\mathrm{JCS}$ & & & & & \\
\hline $\begin{array}{l}\text { Total ACUTE PHYSIOLOGY } \\
\text { SCORE (APS) } \\
\text { Sum of the } 12 \text { individual variable } \\
\text { points }\end{array}$ & & & & & & & & & \\
\hline $\begin{array}{l}\text { SERUM HCO3 (venous-mMol/L) } \\
\text { use only if no ABGs }\end{array}$ & $>52$ & $\begin{array}{l}41- \\
51.9\end{array}$ & & $\begin{array}{l}32- \\
40.9\end{array}$ & $\begin{array}{l}22- \\
31.9\end{array}$ & & $\begin{array}{l}18- \\
21.9\end{array}$ & $\begin{array}{l}15- \\
17.9\end{array}$ & $<15$ \\
\hline
\end{tabular}

Add 0 points for the age <44;2 points for 45-54 years; 3 points for 55-64 years; five points for 65-74 years; and 6 points for $\geq 75$ years. 
Table2: SAPS II-Simplified Acute Physiology Score chart (Le Gall et al., 1993)

\begin{tabular}{|c|c|c|c|c|c|c|c|c|c|}
\hline & \multicolumn{4}{|c|}{ HIGH ABNORMAL RANGE } & & \multicolumn{4}{|c|}{ LOW ABNORMAL RANGE } \\
\hline Physiological variable & +4 & +3 & +2 & +1 & 0 & +1 & +2 & +3 & +4 \\
\hline Age (years) & $>75$ & $66-75$ & $56-65$ & $46-55$ & $\geq 45$ & & & & \\
\hline Heart rate (beat/min) & $\geq 180$ & $\begin{array}{l}140- \\
179\end{array}$ & $\begin{array}{l}110- \\
139\end{array}$ & & $70-109$ & & $55-69$ & $40-54$ & $<40$ \\
\hline SBP $(\mathrm{mmHg})$ & $\geq 190$ & & $\begin{array}{l}150- \\
189\end{array}$ & & $80-149$ & & $55-79$ & & $<55$ \\
\hline Glascow Coma Scale (GCS) & 3 & $4-6$ & $7-9$ & $10-12$ & $13-15$ & & & & \\
\hline Respiratory rate (breath/min) & $>50$ & $35-49$ & & $25-34$ & $12-24$ & $10-11$ & $6-9$ & $5-4$ & 3 \\
\hline Body temperature $\left({ }^{\circ} \mathrm{C}\right)$ & $\geq 41$ & $\begin{array}{l}39- \\
40.9\end{array}$ & & $\begin{array}{l}38.5- \\
38.9\end{array}$ & $36-38.4$ & $\begin{array}{r}34- \\
35.9\end{array}$ & $32-33.9$ & $30-31.9$ & $<30$ \\
\hline $\begin{array}{lll}\begin{array}{l}\text { Urinary } \\
\text { hours) }\end{array} & \text { output } & \text { (Litre/24 } \\
\end{array}$ & & & $\geq 5$ & $\begin{array}{l}3.5- \\
4.99\end{array}$ & $\begin{array}{l}0.70- \\
3.49\end{array}$ & & $\begin{array}{l}0.50- \\
0.69\end{array}$ & $\begin{array}{l}0.20- \\
0.49\end{array}$ & $<0.20$ \\
\hline Hematocrit (\%) & $\geq 60$ & & $50-59.9$ & $46-49.9$ & $30-45.9$ & & $20-29.9$ & & $<20$ \\
\hline $\begin{array}{l}\text { White blood cells count cell } \\
(1000 / \mu \mathrm{L})\end{array}$ & $\geq 40$ & & $20-39.9$ & $15-19.9$ & $3-14.9$ & & $1-2.9$ & & $<1$ \\
\hline Serum glucose $(\mathrm{mg} / \mathrm{dL})$ & $\geq 800$ & $\begin{array}{l}500- \\
799\end{array}$ & & $\begin{array}{l}250- \\
499\end{array}$ & $70-249$ & & $50-69$ & $29-49$ & $<29$ \\
\hline Serum potassium (mEq/L) & $\geq 7$ & $6-6.9$ & & $5.5-5.9$ & $3.5-5.4$ & $3-3.4$ & $2.5-2.9$ & & $<2.5$ \\
\hline Blood urea nitrogen $(\mathrm{mg} / \mathrm{dL})$ & & $\geq 154$ & $\begin{array}{l}101- \\
153\end{array}$ & $81-100$ & $21-80$ & $10-20$ & & $<10$ & \\
\hline Serum $\mathrm{HCO}_{3}(\mathrm{Meq} / \mathrm{L})$ & & $\geq 40$ & & $30-39.9$ & $20-29.9$ & $\begin{array}{l}10- \\
19.9\end{array}$ & & $5-9.9$ & $<5$ \\
\hline Serum sodium $(\mathrm{mEq} / \mathrm{L})$ & $\geq 180$ & $\begin{array}{l}161- \\
179\end{array}$ & $\begin{array}{l}156- \\
160\end{array}$ & $\begin{array}{l}151- \\
155\end{array}$ & $\begin{array}{l}130- \\
150\end{array}$ & & $\begin{array}{l}120- \\
129\end{array}$ & $\begin{array}{l}110- \\
119\end{array}$ & $<110$ \\
\hline
\end{tabular}

Scores are obtained in the first 24 hours of admission., Score=summation of the points for each item.

Table 3: Sequential Organ Failure Assessment (SOFA) score (Vincent et al., 1996)

\begin{tabular}{|l|l|l|l|l|l|}
\hline \multicolumn{1}{|c|}{ SOFA score } & \multicolumn{1}{c|}{$\mathbf{0}$} & \multicolumn{1}{c|}{$\mathbf{2}$} & \multicolumn{1}{c|}{$\mathbf{3}$} & \multicolumn{1}{c|}{$\mathbf{4}$} \\
\hline $\begin{array}{l}\text { Respirationa } \\
\mathrm{PaO}_{2} / \mathrm{FIO}_{2}(\mathrm{~mm} \mathrm{Hg}) \\
\mathrm{SaO}_{2} / \mathrm{FIO}_{2}\end{array}$ & $>400$ & $\begin{array}{l}<400 \\
221-301\end{array}$ & $\begin{array}{l}<300 \\
142-220\end{array}$ & $\begin{array}{l}<200 \\
67-141\end{array}$ & $\begin{array}{l}<100 \\
<67\end{array}$ \\
\hline $\begin{array}{l}\text { Coagulation } \\
\text { Platelets } 10^{3} / \mathrm{mm}^{3}\end{array}$ & $>150$ & $<150$ & $<100$ & $<50$ & $<20$ \\
\hline $\begin{array}{l}\text { Liver } \\
\text { Bilirubin (mg/dL) }\end{array}$ & $<1.2$ & $1.2-1.9$ & $2.0-5.9$ & $6.0-11.9$ & $>12.0$ \\
\hline $\begin{array}{l}\text { Cardiovascular } \\
\text { Hypotension }\end{array}$ & No hypotension & MAP $<70$ & $\begin{array}{l}\text { Dopamine </=5 or } \\
\text { dobutamine (any) }\end{array}$ & $\begin{array}{l}\text { Dopamine }>5 \text { or } \\
\text { norepinephrine } \\
</=0.1\end{array}$ & $\begin{array}{l}\text { Dopamine }>15 \text { or } \\
\text { norepinephrine } \\
>0.1\end{array}$ \\
\hline $\begin{array}{l}\mathrm{CNS} \\
\text { Glasgow Coma Score }\end{array}$ & 15 & $13-14$ & $10-12$ & $6-9$ & $<6$ \\
\hline $\begin{array}{l}\text { Renal } \\
\text { Creatinine (mg/dL) } \\
\text { or urine output } \\
\text { (mL/d) }\end{array}$ & $<1.2$ & $1.2-1.9$ & $2.0-3.4$ & $3.5-4.9$ or $<500$ & $>5.0$ or $<200$ \\
\hline
\end{tabular}

$M A P$, mean arterial pressure; $C N S$, central nervous system; $\mathrm{SaO}_{2}$, peripheral arterial oxygen saturation.

${ }^{a} \mathrm{PaO}_{2} / \mathrm{FIO}_{2}$ ratio was used preferentially. If not available, the $\mathrm{SaO}_{2} / \mathrm{FIO}_{2}$ ratio was used; ${ }^{b}$ vasoactive mediations administered for at least $1 \mathrm{hr}$ (dopamine and norepinephrine $\mathrm{ug} / \mathrm{kg} / \mathrm{min}$ ). 
Table (4): causes of death in the non survivors group.

\begin{tabular}{|l|l|l|}
\hline \multicolumn{1}{|c|}{ Cause of death } & Patient No. & Patient \% \\
\hline Respiratory failure & 24 & 86 \\
\hline Premature ventricular contractions & 4 & 14 \\
\hline Total & 28 & 100 \\
\hline
\end{tabular}

Table (5): statistical analysis of Student " $t$ " test between plasma butyrylcholinesterase and scoring systems in survivors and non survivors.

\begin{tabular}{|c|c|c|c|}
\hline & Survivors $(n=45)$ & Non survivors $(\mathrm{n}=\mathbf{2 8})$ & Independent t-test \\
\hline & Mean \pm SD & Mean \pm SD & p-value \\
\hline Plasma butyrylcholinesterase (IU) & $1238 \pm 792$ & $949 \pm 362$ & $\begin{array}{l}0.074 \\
\text { insignificant }\end{array}$ \\
\hline Delay time (min) & $226 \pm 96$ & $251 \pm 129$ & 0.347 \\
\hline APACHE II & $5.6 \pm 3.7$ & $13.1 \pm 7.3$ & $\begin{array}{l}<0.0001 \\
\text { highly significant }\end{array}$ \\
\hline SAPS II & $16.5 \pm 5.5$ & $30.6 \pm 11.7$ & $\begin{array}{l}<0.0001 \\
\text { highly significant }\end{array}$ \\
\hline SOFA & $1.02 \pm 0.97$ & $5.75 \pm 3.5$ & $\begin{array}{l}<0.0001 \\
\text { highly significant }\end{array}$ \\
\hline
\end{tabular}

Table (6): statistical analysis of best cut off values for APACHE II, SAPS II, and SOFA scoring systems.

\begin{tabular}{|c|c|c|c|c|c|c|}
\hline $\begin{array}{l}\text { Scoring } \\
\text { system }\end{array}$ & $\begin{array}{c}\text { Area under the } \\
\text { curve (AUC) }\end{array}$ & $\begin{array}{c}\text { Cut } \\
\text { off }\end{array}$ & $\begin{array}{c}\text { Sensitivity (95\% } \\
\text { CI) }\end{array}$ & $\begin{array}{c}\text { Specificity }(95 \% \\
\text { CI) }\end{array}$ & $\begin{array}{c}\text { Likelihood } \\
\text { ratio }\end{array}$ & P value \\
\hline APACHE II & $0.777 \pm 0.058$ & $\begin{array}{l}> \\
10.5\end{array}$ & $\begin{array}{l}53.57(33.87 \% \text { to } \\
72.49 \%)\end{array}$ & $\begin{array}{l}97.78(88.23 \% \text { to } \\
99.94 \%)\end{array}$ & 24.11 & $\begin{array}{l}<0.0001 \\
\text { highly } \\
\text { significant }\end{array}$ \\
\hline SAPS II & $0.8107 \pm 0.064$ & $\begin{array}{l}> \\
25.0\end{array}$ & $\begin{array}{l}75.00(55.13 \% \text { to } \\
89.31 \%)\end{array}$ & $\begin{array}{l}84.44(70.54 \% \text { to } \\
93.51 \%)\end{array}$ & 4.821 & $\begin{array}{l}<0.0001 \\
\text { highly } \\
\text { significant }\end{array}$ \\
\hline SOFA & $0.8548 \pm 0.052$ & $\begin{array}{l}> \\
2.50\end{array}$ & $\begin{array}{l}75.00(55.13 \% \text { to } \\
89.31 \%)\end{array}$ & $\begin{array}{l}91.11(78.78 \% \text { to } \\
97.52 \%)\end{array}$ & 8.438 & $\begin{array}{l}<0.0001 \\
\text { highly } \\
\text { significant }\end{array}$ \\
\hline
\end{tabular}

CI: confidence interval

Table (7):percentage of mortalities predicted by the three scoring systems

\begin{tabular}{|l|l|l|l|c|}
\hline Scoring system & $\begin{array}{c}\text { Actual } \\
\text { Mortality }(\boldsymbol{\%})\end{array}$ & $\begin{array}{c}\text { Predicted } \\
\text { Mortality }(\boldsymbol{\%})\end{array}$ & Standardized mortality ratio (SMR) & 95\% CI \\
\hline APACHE II & 38 & 30 & 1.27 & $0.93-1.67$ \\
\hline SAPS II & 38 & 37 & 1.03 & $0.76-1.35$ \\
\hline SOFA & 38 & 34 & 1.12 & $0.82-1.45$ \\
\hline
\end{tabular}

CI: confidence interval 


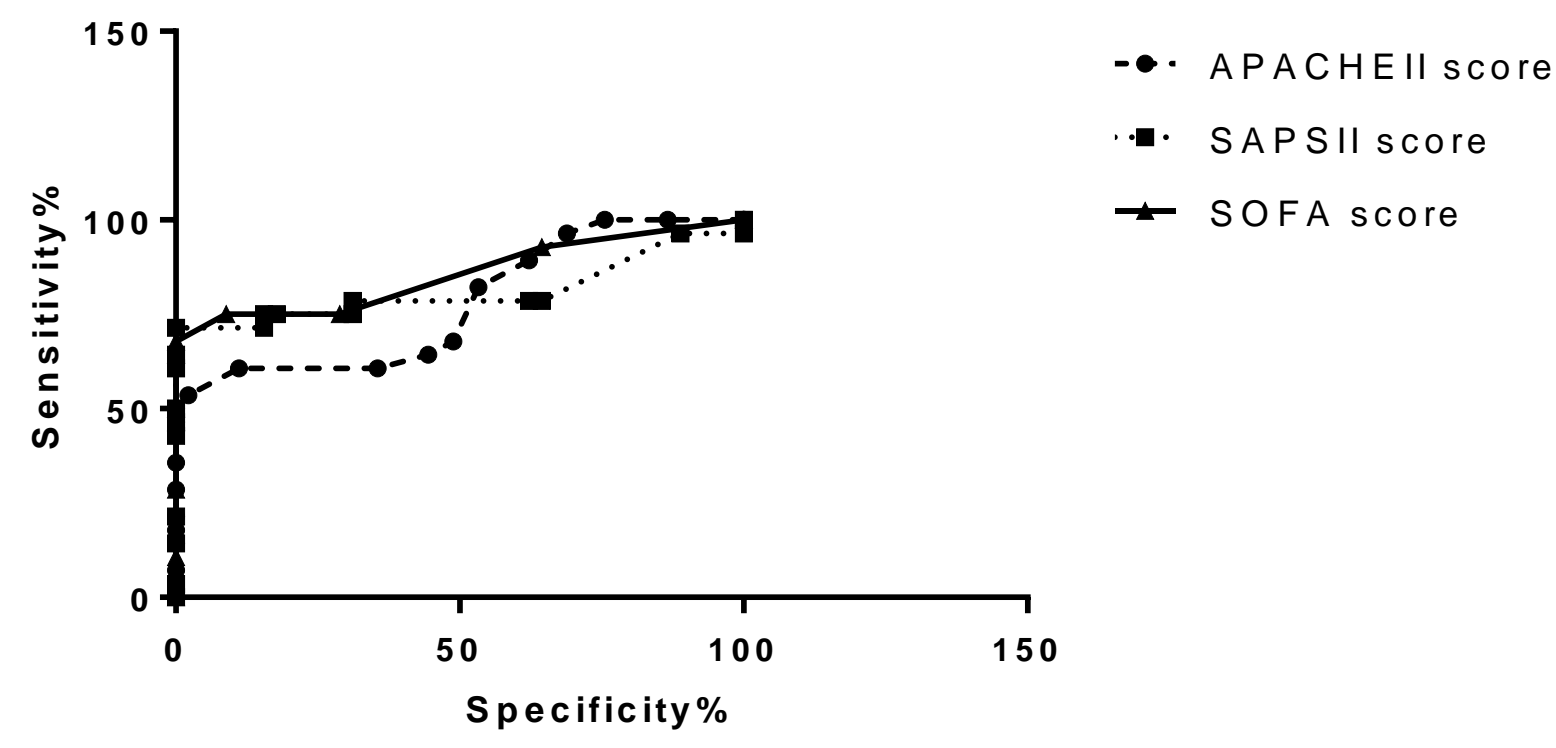

Figure 1: ROC curve comparing the ability of APACHE II, SAPS II, and SOFA scoring systems to predict mortality in OP poisoned patients admitted to the ICU.

\section{Discussion}

Triage of OP poisoning patients is one of the important issues in their treatment. Unfortunately, no single sign or symptom has been found to prognosticate acute OP poisoning mortality (Bilgina et al., 2005). Although the plasma or urine OP concentrations and serum cholinesterase levels strongly correlate with the mortality rate, these laboratory methods are not always available (Davies et al., 2008). The present study aimed to assess the effectiveness of APACHE II, SAPS II and SOFA scoring systems to predict the outcome of OP poisoning.

The effect of time delay on the clinical picture of OP poisoning patients can be expected, as the management of OP poisoning includes 4 stages; initial stabilization of patients by maintaining respiration and other vital signs; reduction of exposure, administration of specific antidote, and supportive treatment. All these 4 stages are affected by prolonged time delay before attending the hospital (Ahmad et al., 2009). Time delay is important, as late arrival to the hospital may prevent oximes from reactivating the cholinesterase as it has already aged. Ageing is an important issue because it determines whether a patient poisoned by a particular OP will benefit from oximes (Worek et al., 2010).

The studies are controversial about the relationship between butyrylcholinesterase and OP poisoning severity, but the dominant view is that there is no relationship. No difference was observed between survivors and non survivors in the study of Shandia et al. (2007). Rehiman et al. (2008) observed significant correlation between serum cholinesterase level and severity of OP poisoning at the initial presentation.
Cander et al (2011) stated that butyrylcholinesterase levels did not correlate statistically with mortality or length of stay.

The absence of significant correlation between serum cholinesterase and OP poisoning severity can be explained by the inter-individual and inter-chemical variability in the degree and duration with which the organophosphorus compounds affect various cholinesterases. Short-term exposures can depress cholinesterase activity to very low levels with minimal symptoms. This variation may lead to the difference in clinical presentation as some patients may be severely symptomatic although there is minimal reduction in cholinesterase activity, while others can be asymptomatic after losing $50 \%$ of the activity of cholinesterases (Clark, 2006). The degree of $\mathrm{ChE}$ inhibition is not uniformly correlated with cholinergic dysfunction, probably because the amount of cholinesterase varies among tissues. Moreover, the cholinergic system shows remarkable plasticity, allowing modulations to compensate for dysfunctions of this pathway (Eyer et al., 2009).

The APACHE II uses a point score consisting of the initial values of 12 routine physiological measurements, in addition to patient age and medical history to provide a measure of disease severity. This system stratifies patients according to prognosis (Kanus et al., 1985). In this study, APACHE II score was useful for predicting the outcome of OP poisoned patients with a cut off value of 10.5 points.

SAPS II is calculated from 12 routine physiological measurements in the first $24 \mathrm{hr}$, in addition 
to information about health status, giving the predicted mortality (Le Gall et al., 1993). SAPS II was useful for predicting the outcome of OP poisoned patients in our study, with a cut off value of 25 points.

The SOFA score calculates a summary value for six organs (respiratory, coagulation, liver, cardiovascular, central nervous system, and renal) (Vincent et al., 1996). In the present study, although SOFA scores were calculated on the day of admission, they predicted the outcome of OP poisoned patients admitted to ICU with a cut off value of 2.5 points. Although the three scoring systems were not statistically different from each other, the SOFA score was easier to apply compared to APACHE II and SAPS II scores.

The results of the present study were comparable to the results of other studies. Yen et al. (2000) reported higher APACHE II scores in OP poisoning patients who died. Huang et al. (2003) concluded that the mortality rate was $95 \%$ in patients with an APACHE II score of over 20. Bilgin et al (2005) found both APACHE II and SAPS II systems to have an equal ability to predict the mortality in OP poisoning. Sungurtekin et al (2006) concluded that the APACHE II, III and SAPS II clinical scoring tools seem to predict the severity of organophosphate poisoning, and may have prognostic value.

Lee and Tai (2001) stated that APACHE II score may be used as an alternative index of severity in patients with OP poisoning. The usefulness of APACHE II score as a predictor of OP poisoned patients' mortality was confirmed by the study of Kang et al. (2009). Kim et al (2013) found that APACHE II, SAPS II, and SOFA scores were equal in predicting $\mathrm{OP}$ poisoned patients mortality.

\section{Conclusion}

This study shows that the APACHE II, SAPS II, and SOFA scoring systems on admission are able to predict death in patients with OP poisoning with similar accuracy, however, the SOFA is much easier to apply clinically. Using a cut off of 2.5 points or more was predictive of mortality, with $75 \%$ sensitivity and $91 \%$ specificity. These scoring systems can be used to determine the need for ICU admission and direct further treatment of OP poisoned patients, especially in resource limited areas, with limited number of ICU beds.

This study used data collected on admission and did not evaluate the ability of the scoring systems to predict outcome after admission.

\section{Recommendations}

Further studies including the serial measurements of these scores may be needed; the change in these scores may be more accurate than single absolute value, especially if the patients with intermediate syndrome were considered.

\section{References}

Ahmad M, Rahman F, Ashrafuzzaman M, Chowdhury D and Ali M (2009): Overview of organophosphorus compound poisoning in Bangladesh and medicolegal aspects related to fatal cases.JAFMC Bangladesh. Vol 5, No 1.

Bazari H (2007): Approach to the patient with renal disease. In: Cecil Medicine, 23rd edition, Goldman L and Aussiello D (editors), Saunders Elsevier. Philadelphia; pp: 1720-79.

Bewick V, Cheek L, and Ball J. (2004): Statistics review 13: receiver operating characteristic curves.Crit Care;8:508-12.

Bilgin TE, Camdeviren H, Yapici D, Doruk N, Altunkan AY, Altunkan Z, and Oral U. (2005): The comparison of the efficacy of scoring systems in organophosphate poisoning. Toxicology and Industrial Health;21:141-146

Bilgina TE, Camdeviren H, Yapicia D, Doruka N, Altunkana AA, Altunkana Z, and Orala U. (2005): The comparison of the efficacy of scoring systems in organophosphate poisoning. Toxicol Indust Health; 21:141-46

Cander B, Dur A, Yildiz M, Koyuncu F, Girisgin AS, Gul M, and Okumus M. (2011): The prognostic value of the Glasgow coma scale, serum acetylcholinesterase and leukocyte levels in acute organophosphorus poisoning. Ann Saudi Med; 31(2): 163-166.

Clark R (2006): Insecticides: Organic Phosphorus Compounds and Carbamates. In: Goldfrank LR, Flomenbaum NE, and Lewis NA (eds): Goldfrank's Toxicologic Emergencies, 8th edition. New York, McGraw-Hill, pp 14981512.

Davies JOJ, Eddleston M and Buckley NA. (2008): Predicting outcome in acute organophosphorus poisonin with a poison severity score or the Glasgow coma scale. Q J Med;101:371-379

Eddleston M, Buckley N, Checketts H, Senarathna L, Mohamed F, Sheriff M and Dawson A (2004): Speed of initial atropinisation in significant organophosphorus pesticide poisoning - a systematic comparison of recommended regimens. J Toxicol Clin Toxicol;42:865-75.

Eyer P, Worek F, Thiermann H and Eddleston M (2009): Paradox findings may challenge orthodox reasoning in acute organophosphate poisoning. Available from: http://www.sciencedirect.com.

Faix JD (2000): In: Interpretation of dignostic Tests; 7th ed.;. Wallach J (editor), Lippincott Williams and Wilkins. Philadelphia; pp: 1026.

Goldhill D.R. and Sumner, A. (1998): Outcome of intensive care patients in a group of British Intensive care units. Critical Care Medicine26, $1337 / 45$. 
Hargrove J and Nguyen HB. (2005): Bench-to-bedside review: outcome predictions for critically ill patients in the emergency department. Crit Care;9:376-383.

Huang, N.C., Lin, S.L., Hung, Y.M.et al. (2003): Severity assessment in acute paraquat poisoning by analysis of APACHE II score.Journal of the Formosan Medical Association102, 782 /19.

Jalali1 N, Pajoumand A, Abdollahi M, Shadnia S, and Pakravan N. (2003): Pesticides poisoning, oneyear report ofLoghman-Hakim hospital poison center. Prog Med Res, 1(52): 1-9.

Kane SP. (2015): Combination ICU Mortality Calculator (APACHE II, SAPS II, SOFA). ClinCalc: //clincalc.com/IcuMortality/Default.aspx. Updated January 16, 2015. Accessed July 13, 2015.

Kang EJ, Seok SJ, Lee KH, Gil HW, Yang JO, Lee EY, and Hong SY. (2009): Factors for determining survival in acute organophosphate poisoning The Korean Journal of Internal Medicine Vol. 24, No. 4

Kim YH, Yeo JH, Kang MJ, Lee JH, Cho KW, Hwang SY, Hong CK, Lee YH and Kim YW. (2013): Performance assessment of the SOFA, APACHE II scoring system, and SAPS II in intensive care unit organophosphate poisoned patients. J Korean Med Sci;28(12):1822-1826

Knaus WA, Draper EA, Wagner DP, and Zimmermam JB (1985): APACHE II: A severity of disease classification system.Critial care medicine13: 818-829.

Lawrence M, and Robert H C, (1993): Methods of determination of blood urea nitrogen and serum creatinine. In: Tietz textbook of clinical chemistry.2nd edition, W B Saunders Company, London, pp 621.

Le Gall JR, Lemeshow S, and Saulnier F. (1993): A new Simplified Acute Physiology Score (SAPS II) based on a European/North American multicenter study. JAMA;270(24):2957-63.

Lee P, Tai DY. (2001): Clinical features of patients with acute organophosphate poisoning requiring intensive care. Intensive Care Med;27:694-699.

Lehman R and Krumholz H (2009): Tight control of blood glucose in long standing type 2 diabetes. BMJ; 338-800.
Novros JS, Koch TR, and Knoblock EC. (1979): Improved method for accurate quantitation of total and conjugated bilirubin in serum. Clin Chem;25:1891-1899.

Rehiman S, Lohani SP and Bhattarai MD. (2008): Correlation of serum cholinesterase level, clinical score at presentation and severity of organophosphorous poisoning. J Nepal Med Assoc;47(170):47-52

Shadnia S, Salimi A and Abdollahi M. (2007): A simplified acute physiology score in the prediction of acute organophosphate poisoning outcome in an intensive care unit. Human \& Experimental Toxicology; 26:623-627

Sungurtekin H, Gürses E and Balci C. (2006): Evaluation of several clinical scoring tools in organophosphate poisoned patients. Clinical Toxicology Volume 44, Issue 2, pages 121-126

Vincent JL, Moreno R, Takala J, Willatts S, De Mendonça A, Bruining H, Reinhart CK, Suter PM, and Thijs LG. (1996): The SOFA (Sepsisrelated Organ Failure Assessment) score to describe organ dysfunction/failure. On behalf of the Working Group on Sepsis-Related Problems of the European Society of Intensive Care Medicine. Intensive Care Med;22(7):707-10.

Waber H (1966): Kinetic colorimetric method for detection of cholinesterase. Dtsch Med Wschr; 91: 1927.

Worek F, Eyer P, Aurbek N and Thiermann H (2010): Kinetic Analysis of Oxime Interactions with Acetylcholinesterase as a Basis for the Evaluation of Oxime Efficacy in Organophosphate Poisoning. Volume 6, Number 1,pp. 16-22(7).

World Health Organization (2011): WHO recommended classification of pesticides by hazard and guidelines to classification 2010-2011. WHO/PCS/01.4. Geneva: World Health Organization.

Yen, D.H.T., Yien, H.W., Wang, L.M.et al. (2000): Spectral analysis of systemic arterial pressure and heart rate signals of patients with acute respiratory failure induced by severe organophosphate poisoning.Critical Care Medicine 28, 2805/11. 


\section{الملخص العربح}

اباشى Y , سابس Y و سوفا انظمة تقييم استخدمت للتنبؤ بمآل حالات التسمم الحاد بمركبات الفوسفات العضوية التى ادخلت الى الرعاية المركزة بمركز علاج ج التسمم بمستشفيات جامعة عين شمس (دراسة مستقبلية)

\section{نسرين محمد سرحان}

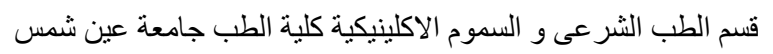

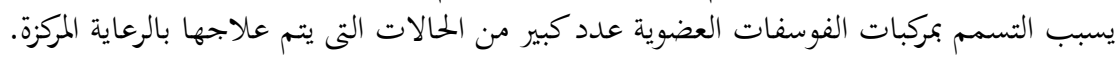

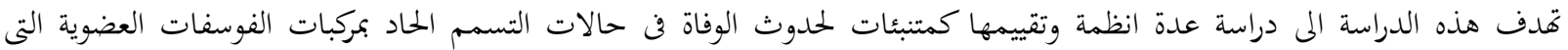

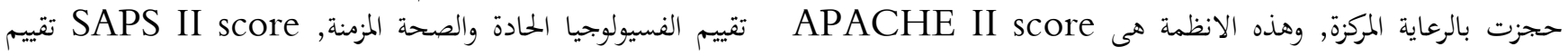

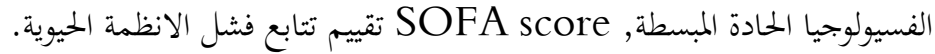

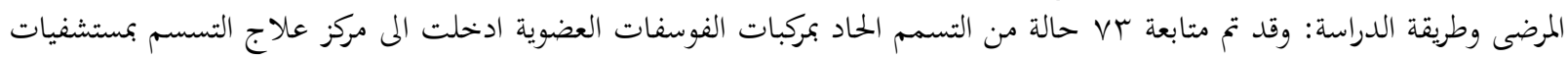

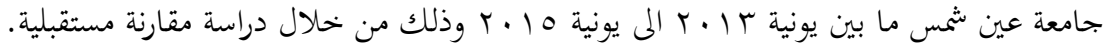

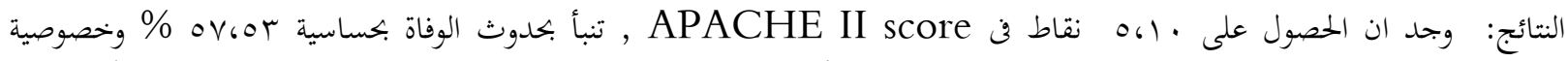

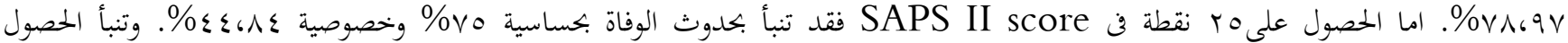

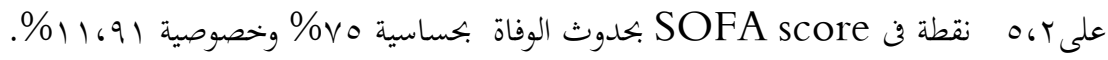

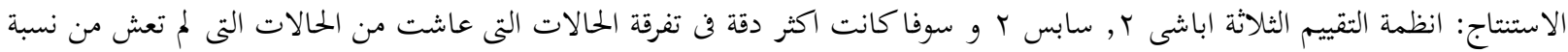
انزيم الكولين استراز بالبلازما. ا قسم الطب الثرعي و السموم الإكلينيكية، كلية الطب، جامعة عين شمس، القاهرة, مصر. 